\title{
TWO NEW SPECIES OF EPISTEPHIUM (ORCHIDACEAE, VANILLOIDEAE) FROM COLOMBIA
}

\author{
DARIUSZ L. SZlaChETKO \& MARTA KOLANOWSKA ${ }^{1}$
}

\begin{abstract}
Two new species of Neotropical Orchidaceae, Epistephium epiphyticum Szlach. \& Kolan. and E. cardonae Szlach. \& Kolan., are described and illustrated based on Colombian material. So far the new entities are known exclusively from the type locations. Both species are placed within a key to Colombian Epistephium Kunth.
\end{abstract}

Key words: biodiversity, Neotropics, South America, taxonomy

Dariusz L. Szlachetko \& Marta Kolanowska, Department of Plant Taxonomy and Nature Conservation, University of Gdańsk, ul. Wita Stwosza 59,80-308 Gdańsk, Poland; e-mail: martakolanowska@wp.pl

\section{INTRODUCTION}

The genus Epistephium Kunth was proposed by Karl Kunth (1822) in Synopsis Plantarum Aequinoctialium Orbis Novi. The generic name is derived from the Greek epi- ('upon') and stephanos ('crown'), referring to the shallow cup, the so-called calyculus, observed at the apex of the ovary. The nominal species of this Neotropical genus is E. elatum Kunth, which was described based on Colombian material.

The genus comprises terrestrial erect plants with chartaceous to coriaceous leaves. Showy flowers are gathered in terminal or axillary racemes. The lip usually is ornamented with a central row of retrorse, barbate or lacerate crests (Cameron 2003). The gynostemium is elongate, more or less incurved at the apex only. The conspicuous column part is connate with the lip in the lower half. The anther is incumbent, ellipsoid-ovoid to ellipsoid-conical, motile and 2-chambered. The four pollinia are oblong and very powdery. The 3-lobed ventral stigma is transversely elliptic, cuplike, and deeply concave in the center (Szlachetko \& Rutkowski 2000).

So far ca 25 species of Epistephium have been described (Carnevali \& Ramírez-Morillo 2003),

\footnotetext{
1 Corresponding author
}

10 of them recorded from Colombia (Ortiz Valdivieso \& Uribe Vélez 2007). Their occurrence was reported from northern Argentina to Guiana and Belize. The plants usually are found growing in open grassy areas or savannas on lateritic soil. The altitudinal range of Epistephium extends from $100 \mathrm{~m}$ up to $1200 \mathrm{~m}$ a.s.l. (Garay 1978; Cameron 2003; Carnevali \& Ramírez-Morillo 2003).

The genus is poorly understood due to the insufficiency of herbarium collections and difficulties in hydrating and examining flowers from dried material. A comprehensive revision of the herbarium material stored in the National Colombian Herbarium produced descriptions of five new Epistephium species (Szlachetko et al. 2013a, b).

Recent studies of Columbian vanilloid orchids revealed the existence of another two species of the genus, described here as new.

\section{DESCRIPTIONS OF THE NEW SPECIES}

Epistephium epiphyticum Szlach. \& Kolan., sp. nov.

Fig. 1

Epiphytic plant characterized by sessile leaves, petals subequal in width to sepals and entire, ovate lip, nearly free from the gynostemium and ornamented with several 


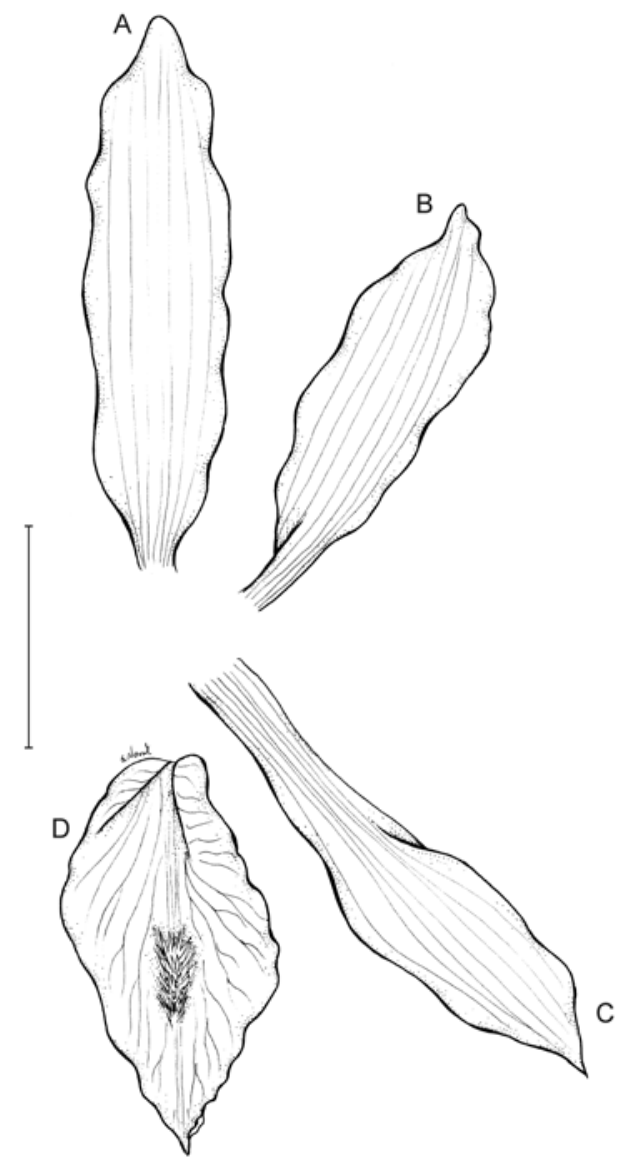

Fig. 1. Epistephium epiphyticum Szlach. \& Kolan. - dissected perianth. A - dorsal sepal; B - petal; C - lateral sepal; D - lip. Drawn by $\mathrm{S}$. Nowak from the holotype. Scale bar $=20 \mathrm{~mm}$.

folds running from the base up to the lip apex, and a crest of subulate appendages in the central part.

Holotype: COLOMBIA, Antioquia. Mun. Santo Domingo, Correg. Santiago, sector La Negra, $9 \mathrm{~km}$ de Santiago, 13 Aug. 1986, R. Callejas, S. Churchill, P. Acebedo, C. J. Castańo \& M. Escobar 2382 (HUA).

Stem erect, over $50 \mathrm{~cm}$ high. Leaves $9-13 \mathrm{~cm}$ long, 3.5-6.0 cm wide, ovate-lanceolate to ovate, acute or short-acuminate, cordate at base. Inflorescence terminal, erect, $c a 25 \mathrm{~cm}$ long, several-flowered, rather dense. Flowers $4-5 \mathrm{~cm}$ long, \pm thin in texture, purplish, fragrant. Floral bracts $7-9 \mathrm{~mm}$ long, cymbiform, acute. Ovary up to $17 \mathrm{~mm}$ long, cylindrical, sessile, crowned with shallow denticulate cup. Dorsal sepal 48-50 mm long, ca $13 \mathrm{~mm}$ wide, oblong, obtuse. Lateral sepals $46-48 \mathrm{~mm}$ long and 10-11 mm wide, oblong, acute. Petals 38-40 mm long, 9-10 mm wide, oblong-elliptic, obtuse. Lip 28-30 mm long, 19-20 mm wide, nearly free from the column, ovate in outline, undulate, apex short-acuminate, subacute, recurved; disc with several folds running from base up to lip apex, ornamented in center by crest of subulate appendages extending for $\mathrm{ca} 10 \mathrm{~mm}$. Gynostemium elongate, slender, erect.

ETYMOLOGY. In reference to the epiphytic life form.

HABITAT AND ECOLOGY. Epiphytic in humid tropical forest at $c a 1150 \mathrm{~m}$ a.s.l. Flowering in August.

Distribution. Known only from the Colombian Central Cordillera (Fig. 2).

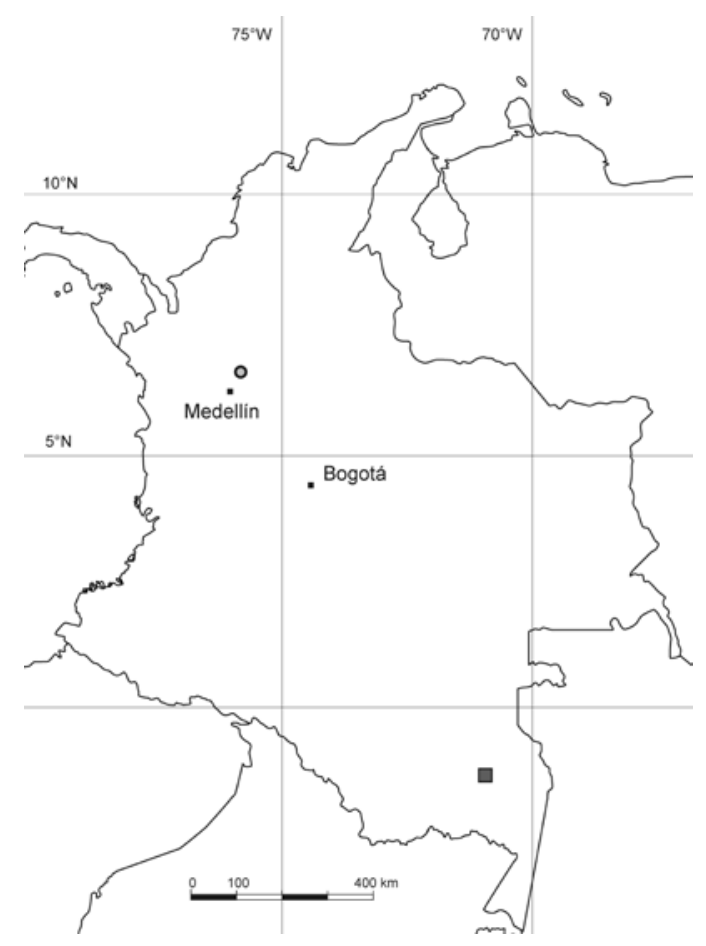

Fig. 2. Distribution of Epistephium epiphyticum Szlach. \& Kolan. (circle) and E. cardonae Szlach. \& Kolan. (square) in Colombia. 
NoTES. This species resembles E. amplexicaule (Ruiz \& Pav.) Poepp. \& Endl. and E. fredericiaugusti Rchb. f. but is easily distinguished from both of them by having small floral bracts and a smaller lip, ovate in outline, with an acute recurved apex and ornamented with a crest of subulate appendages in the central part. The unique feature of E. epiphyticum is its lip nearly free from the gynostemium.

The new species was found in humid tropical forest, a habitat uncommon for the genus; most Epistephium species prefer open areas characterized by warm climate. This is the first report of an epiphyte within the genus.

Epistephium cardonae Szlach. \& Kolan., sp. nov.

Fig. 3

Terrestrial plant characterized by shortly petiolate leaves and an entire quadrate-orbicular lip ornamented with 3 longitudinal folds and retrorsely bearded in the apical part.

Holotype: COLOMBIA, Amazonas. Santa Isabel, sitio sabanas de Solarte, $71^{\circ} 10^{\prime} \mathrm{W} 1^{\circ} 05^{\prime} \mathrm{S}$. 4-6 Dec. 1996, M. V. Arbeláez, U. Matapi \& N. Matapi 690 (HUA).

Stem branching, at least $100-150 \mathrm{~cm}$ tall, sometimes over $150 \mathrm{~cm}$ tall. Leaves basally attenuate into short petiole $2.5-3.0 \mathrm{~cm}$ long, blade up to $13 \mathrm{~cm}$ long, $2.3-4.5 \mathrm{~cm}$ wide, lanceolate, ovate-lanceolate or lanceolate-elliptic, shortly acuminate, acute. Inflorescences few, axillary, racemose, up to $c a 15 \mathrm{~cm}$ long, several-flowered. Flowers purplish, $c a 2.5 \mathrm{~cm}$ long. Floral bracts minute, ca $2.5 \mathrm{~mm}$ long, triangular-ovate. Ovary up to $35 \mathrm{~mm}$ long, sessile, crowned with shallow cup. Dorsal sepal 24-25 mm long, 3.8-4.0 mm wide, oblong-lanceolate, acute. Lateral sepals 16-17 mm long, 3.8-4.0 mm wide, obliquely oblong, obtuse to short acuminate. Petals 19-20 $\mathrm{mm}$ long, 2.7-4.0 $\mathrm{mm}$ wide, oblong-elliptic, acute. Lip 15-16 $\mathrm{mm}$ long, 5.2-5.5 mm wide, shortly clawed, quadrate-orbicular in outline, acute and shortly acuminate at apex, margins undulate; disc with 3 longitudinal folds, retrorsely bearded on apical 1/3. Gynostemium elongate, slender, erect.

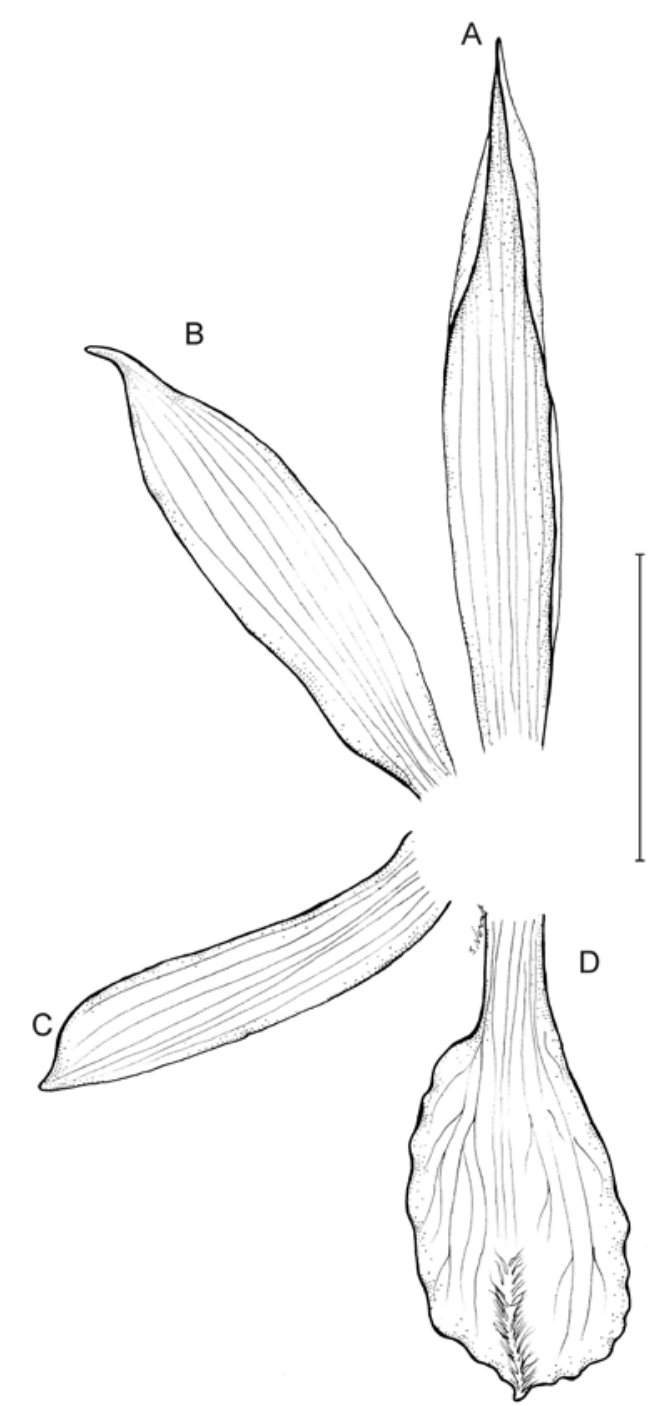

Fig. 3. Epistephium cardonae Szlach. \& Kolan. - dissected perianth. A - dorsal sepal; B - petal; C - lateral sepal; D - lip. Drawn by S. Nowak from the holotype. Scale bar $=10 \mathrm{~mm}$.

ETYMOLOGy. Named to honor Felipe Alfonso Cardona Naranjo, Curator of the herbarium of the University of Antioquia (HUA).

HABITAT AND ECOLOGY. Grows in scrub on white sand and decaying organic matter at 100 $150 \mathrm{~m}$ elev. Flowering in December.

DistribUTION. Known only from the Colombian department of Amazonas (Fig. 2). 
NoTES. This species resembles E. parviflorum Lindl., from which is easily distinguished by its narrower lip bearded on the apical 1/3 (vs lip basally retrorsely bearded) and longer leaf petiole (2.5-3.0 cm vs $0.5-0.6 \mathrm{~cm}$ long).

\section{KEY TO THE COLOMBIAN SPECIES OF EPISTEPHIUM}

1. Plants small, $8-23 \mathrm{~cm}$ tall. Leaves shortly petiolate, elliptic to elliptic-obovate, widest near middle or above ... E. ellipticum R. O. Williams \& Summerh.

1. Plants much higher, at least $40 \mathrm{~cm}$ tall, usually much taller. Leaves sessile or petiolate, oblong-lanceolate to broadly elliptic-ovate, widest in basal part .... 2

2. Leaves amplexicaul .............. 3

2. Leaves non-amplexicaul ........... 12

3. Lip orbicular or ovate to transversely elliptic, truncate, acuminate or shortly apiculate at apex ...4 4

3. Lip \pm oblong-obovate, \pm incised at apex . . . . . 5

4. Lip orbicular in outline, disc papillose-barbate along median nerve in upper half .......... $\ldots \ldots \ldots \ldots$ E. frederici-augusti Rchb. f.

4. Lip ovate to transversely elliptic in outline, disc with only a tuft of fleshy hairs or subulate appendages in center ................ 6

5. Lip transversely elliptic in outline, wider than long ... E. rhombilabium Szlach., Mytnik \& Baranow 5. Lip ovate in outline, longer than wide ......... E. epiphyticum Szlach. \& Kolan.

6. Lamellae or hairs running from base to apex of lip lamina .................. 7

6. Cristate lamellae or hairs of various kinds present only in lip center .............. 9

7. Floral bracts up to $15 \mathrm{~mm}$ long, sepals to $30 \mathrm{~mm}$ long, thick and stiff, lip covered by $8 \mathrm{~mm}$ long hairs along midvein $\ldots \ldots \ldots \ldots \ldots \ldots \ldots \ldots \ldots$ ....... E. trianae Szlach., Mytnik \& Baranow

7*. Not showing above combination of features ... 8

8. Lip in basal $23 \mathrm{~mm}$ connate with gynostemium; free part broadly rhombic or broadly ovate, margins more or less undulate, crenulate-serrulate, adorned in upper part by cuneate, lacerate calli along midvein .... E. lamprophyllum Schltr.

8. Lip nearly free from column, broadly obovate or subrotund, undulate, shortly lacerate and ciliolate at margin; disc through longitudinal center with bearded crest of subulate appendages extending from base nearly to apex, and in front of crest a cluster of numerous folds

E. amplexicaule Poepp. \& Endl.
9. Lip apically deeply incised, hence appearing bilobed ....................... 10

9. Lip sinuously notched at apex . . . . . . . 11

10. Lip with oblique lamella just above base of lip on either side of crest, clinandrium 3-lobed

E. hernandii Garay

10*. Lip without lamellae on sides of central crest, clinandrium unlobed . . . . . E. duckei Huber

11. Floral bracts to $20 \mathrm{~mm}$ long, sepals $10-17 \mathrm{~mm}$ wide, petals $55-66 \mathrm{~mm}$ long and $26 \mathrm{~mm}$ wide .......

........... E. brevicristatum R. E. Schult.

11. Floral bracts to $15 \mathrm{~mm}$ long, sepals to $10 \mathrm{~mm}$ wide, petals to $55 \mathrm{~mm}$ long and to $20 \mathrm{~mm}$ wide .......

E. elatum Kunth

12. Leaves petiolate, petiole very prominent, at least $1 \mathrm{~cm}$ long $\ldots \ldots \ldots \ldots \ldots \ldots \ldots \ldots$

$12^{*}$ Leaves sessile or subsessile, petiole up to $0.5 \mathrm{~cm}$ long if present $\ldots \ldots \ldots \ldots \ldots \ldots \ldots \ldots$

13. Petals $c a 4$ times longer than wide, lip prominently clawed, fleshy hairs along midvein in upper part of lip $\ldots \ldots \ldots \ldots \ldots$ E. parviflorum Lindl.

13. Petals up to twice longer than wide . . . . . . 14

14. Lip shortly clawed, $16 \times 5.5 \mathrm{~mm}$, quadrateorbicular in outline ................ ......... E. cardonae Szlach. \& Kolan.

14. Lip sessile, $20-23 \times 18-24 \mathrm{~mm}$, deltoid in outline ........... E. sessiliflorum Lindl.

15. Flowers small, sepals up to $25 \mathrm{~mm}$ long .... 16 $15^{*}$. Flowers medium-sized, sepals over $35 \mathrm{~mm}$ long ......................... 17

16. Lip transversely elliptic-flabellate in outline, disc strongly thickened and covered by soft hairs along midvein in basal half, and by very long

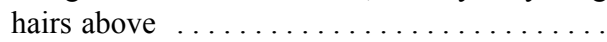
..... E. garayi Szlach., Mytnik \& Baranow

16. Lip almost orbicular in outline, disc with two lamellae running from base to the center of lip, covered by long hairs (to $5 \mathrm{~mm}$ long) from center to apex of lip along midveins ............

E. subrepens Hoehne

17. Leaves subsessile

.... E. kubiyuense Szlach., Mytnik \& Baranow

17 . Leaves shortly petiolate . . . . . . . . . . 18

18. Lip with oblong thickening running from base of claw to apex of lamina, covered densely by fleshy soft hairs .... E. sclerophyllum Lindl.

18. Lip without oblong thickening, central part with crested lamellae, densely hairy above, with two papillate keels below

. E. araracuarae Szlach., Mytnik \& Baranow 
ACKNOWLEDGEMENTS. The Curator and staff of HUA are thanked for their kind hospitality and assistance during our visit. We are grateful to Sławomir Nowak for preparing the illustrations and to the anonymous reviewers for helpful suggestions on the manuscript. The research described was supported by the Polish Ministry of Science and Higher Education (grant no. 8124/B/PO1/2011/40).

\section{REFERENCES}

CAmeron K. M. 2003. Epistephium. In: A. M. Pridgeon, P. J. CRibB, M. W. ChaSE \& F. N. RASMUSSEN (eds), Genera Orchidacearum. 3: Orchidoideae (Part Two), Vanilloideae, pp. 306-309. Oxford University Press, Oxford.

CARnevali G. \& Ramírez-Morillo I. M.. 2003. Epistephium. In J. A. Steyermark, P. E. Berry, K. YATSKIEVyCh \& B. K. Holst (eds), Flora of the Venezuelan Guyana 7: 353-356. Missouri Botanical Garden, St. Louis.
GARAY L. A. 1978. Orchidaceae (Cypripedioideae, Orchidoideae, Neottioideae). In: G. HARLING \& B. SPARRE (eds), Flora of Ecuador. 9: 1-305. Department of Systematic Botany, University of Goteborg and Section for Botany, Riksmuseum, Goteborg.

KUNTH K. 1822. Synopsis Plantarum Aequinoctialium orbis novi. 1. Levrault, Paris.

Ortiz Valdivieso P. \& URiBe Vélez C. 2007. Galería de Orquídeas de Colombia (CD edition). Asociación Bogotana de Orquideología, Bogotá.

SzlachetKo D. L. \& RUTKOWSKI P. 2000. Gynostemia Orchidalium. 1. Apostasiaceae, Cypripediaceae, Orchidaceae (Thelymitroideae-Vanilloideae). Acta Bot. Fenn. 169: 1-322.

Szlachetko D. L., MytniK-EJSmont J. \& BARAnOw P. 2013a. Drei neue Epistephium-Arten (Orchidaceae, Vanilloideae). Die Orchidee 64(1): 14-18.

Szlachetko D. L., MytniK-EJSMont J. \& Baranow P. 2013b. New species of the genus Epistephium (Orchidaceae, Vanilloideae). Pl. Syst. Evol. 299: 1519-1522.

Received 13 May 2013 